International Journal of Engineering \& Technology, $9(2)(2020) 520-526$
International Journal of Engineering \& Technology
Website: www.sciencepubco.com/index.php/IJET
Research paper

\title{
Influence of workers performance to implementation of security, safety, health, and sustainability
}

\author{
Sidiq Arya Putra N. ${ }^{1}$ *, Nunung Widyaningsih ${ }^{1}$, Bambang P. K. Bintoro ${ }^{1}$ \\ ${ }^{1}$ Mercu Buana University \\ *Corresponding author E-mail: sidiq.arya290395@gmail.com
}

\begin{abstract}
This study was carried out to investigate and analyze the effect of worker behavior on security, safety, health, and sustainability (In Indonesian referred to as Keamanan, Keselamatan, Kesehatan, and Keberlanjutan or K4). This study employed a descriptive research method using a quantitative approach. The sample/ subject of the study was obtained through a random sample method with a total sample of 55 respondents. Data analysis in this study was conducted using Partial Least Square (PLS); a variant based choice method of the Structural Equation Modeling (SEM) method. This method was used to explain the relationship of an independent variable with its indicators and to illustrate the relationship between an independent and dependent variable using the SmartPLS software. The results of the analysis indicate that K4 was strongly influenced by the behavior of construction workers with the highest significance value in the sequence, namely the workers, attitude, knowledge, and actions.
\end{abstract}

\section{Introduction}

In the construction field, many activities have a risk of danger. Occupational Safety and Health (referred to as Kesehatan dan Keselamatan Kerja or K3) of construction itself is not something new for there are several regulations related to K3 that have existed since 19870 such as Law No. 1 of 1970 concerning Safety. Moreover, there is also regulation issued by the government, namely Government Regulation No. 50 of 2008 concerning SMK3 (Tarwaka, 2017).

Due to the importance of the element of occupational safety and health (K3) for workers, especially in the field of construction, K3 has to be considered in construction activity. Therefore, the government issued the Construction Services Act No. 2 of 2017 article 70 . It is mentioned in the regulation that to realize the construction project, $\mathrm{K} 4$ values have to be possessed and occupational safety and health have to be maintained. They are necessary to consider the sustainability aspect of the work.

Recent problems occur about the majority of work accidents caused by human negligence. For this reason, following Law No. 2 of 2017 related to Construction Services, it is not only K3 but also K4 (Security, Safety, Health, and Sustainability) that needs to take into account. It is also necessary to add about Security, Safety, Health, and Sustainability (L4) where it also took place up to maintenance around the same project.

Besides, the competence and availability of experts were relatively low. Thus, aspects of risk that had not yet been taken into account as well as the role of consultant planners had been not optimal yet. In the field, the number of supervisors was still limited, and the division of roles and responsibilities of superior is not optima. Moreover, the remuneration of construction workers was not yet suitable while the equipment and materials were not following the specifications out according to the rules.

The various building failures that have occurred lately prove that construction safety issues are still being ignored. The need for serious efforts and good coordination between the government and all construction stakeholders becomes urgent to implement K4 in all construction projects.

As an illustration, data on work accident rates based on BPJS Ketenagakerjaan shows an increase in accident rates. In 2017, there were 123,041 work accidents while in 2018 the number increased into 173,105 work accidents with compensation value paid to the victim as much as Rp. 1.2 trillion in total. Most workers who were asked about various things about K4 did not well aware of K4 even though they had heard about it. This means that K4 issues for workers are placed below other issues such as low wages and other rights.

From the problems mentioned above, this study was conducted aimed at:

1) Know and analyze the effect of knowledge on security, safety, health, and sustainability (K4).

2) Find out and analyze the influence of attitude towards security, safety, health, and sustainability (K4).

3) Find out and analyze the effect of actions on security, safety, health, and sustainability (K4). 


\section{Literature study}

\subsection{Worker safety performance}

Safety performance is work behavior related to safety that can be conceptualized by looking at other work behavior that shape work a certain work behavior (Neal \& Griffin, 2002). In other words, safety performance is part of the behavior of workers in the workplace. Meanwhile, Wijayanti argues that safety performance can be divided into two categories including safety participation and safety compliance (Wijayanti, 2008). Safety participation is defined as the attitude of workers who indirectly have a stake in work safety activities, but which influences protecting the workplace environment to remain safe. Whereas safety compliance can be interpreted as the main activities that must be carried out by workers to maintain safety in the workplace.

\subsection{Worker knowledge}

Knowledge is the result of someone's sensing or the result of knowing about an object through his or her five senses (Notoatmojo, 2014). According to Bart (1994 in Nasution, 2014), a person's action based on the knowledge he has will be more viable compared to someone's action that is not based on knowledge. Therefore, knowledge becomes someone's need to find out how someone performs that is right or wrong.

\subsection{Worker attitude}

The attitude is a feeling of agreeing (favorable) or feeling of disagreeing (non-favorable). Besides attitude has 3 (three) main elements, among others: the belief that is an idea and concept of an object, the emotional evaluation of an object, and the tendency to act. These three main elements are interrelated in forming a total attitude.

\subsection{Worker action}

An action is a real form or realization based on knowledge and attitudes that are interrelated and become a real act (Notoatmojo, 2014). Actions are reactions or responses of a person to stimuli in real or open form. The response to the stimulus is stated clearly in the form of action or practice, which can be easily observed or noticed by others. Therefore, it can also be called over attitude. There are 4 (four) levels in action, namely perception, guided response, mechanism, and adaptation.

\subsection{Security, safety, health and sustainability}

Indonesia just enacted a new Construction Service Law No. 2 of 2017 to replacing Law No. 18 of 1999 concerning Construction Service (Law 18/1999), which had been implemented for more than 17 years. The main aims of this new Construction Law are to increase the competitiveness of national construction service in global competition era, and to update and harmonize it with the other existing and relevant laws and regulations, such as Manpower Law, Information and Electronic Transaction Law, and Regional Authority Law. The New Construction Law regulates three types of construction service business, there are construction consultation business services, construction work business and integrated construction business. Based on law No. 2 of 2017 related to construction services, construction work is not only focused on occupational safety and health that focuses on workers, but needs to be added to the security, safety, health, and sustainability of work (K4). K4 contributes to focus on the sustainability of construction projects during construction work to the maintenance of the worksite.

\section{Research methodology}

\subsection{Research type and data analysis}

Based on the method and measurement, this research is categorized in survey research using questionnaires as data source. This research type is quantitative research aiming for describing phenomenon or social symptom quantitatively or analyzing how the phenomenon or social symptoms occurred in the community is connected each other.

Researchers employed a descriptive method with a quantitative approach to conducting a study on certain samples in this study. The data were collected using research instruments, to test the hypotheses that had been set. This study intended to find out and analyze the effect of worker performance (knowledge, attitudes, action) on security, safety, health, and sustainability (K4).

The variables in this study consisted of 3 (three) independent variable (free variable) (X) and 1 (one) dependent variables (bounded variable) (Y). The independent variables of this study were work safety performances consisted of worker knowledge (X1), worker attitude (X2), and worker action (X3). Meanwhile, the dependent variable of this study was security, safety, health, and sustainability (K4).

Data analysis in this study was conducted using researchers using Partial Least Square (PLS). This analysis is an alternative method based on the Structural Equation Modelling (SEM) variant method. The PLS method has its advantages compared to the CB-SEM method for the sample size is not too large ranging from 30-100 and the data do not have to be multivariate normally distributed and also PLS can also be used for structural modeling with indicators that are reflective or formative (Ghozali, 2006).

\subsection{The object of the study}

This study was conducted in the Green Cleosa Ciledug Apartment Development Project in Tangerang. Green Cleosa Ciledug Apartment is a vertical residence that is equipped with four-star hotel facilities. This apartment is in a strategic location, which is on Jl. Raden Fatah No.62, Sudimara Barat, Ciledug, Tangerang.

This residence is suitable as an investment choice residence, because it is flanked by three toll gates, namely the Soekarno-Hatta Airport Toll, Pondok Ranji Toll and Karang Tengah Toll. As a masterpiece from the developer PT Bhakti Agung Propertindo, Green Cleosa Apartment provides an apartment concept with a modern green concept that has a modern and futuristic impression. 
PT Bhakti Agung Propertindo is a subsidiary of the Agung Development Group that has built several property projects, such as Taman Melati Premiere, Puri Primacom, Allegria Apartment, Grand Wastukencana Condotel, Taman Permata Cirebon, and The Palace Apartement \& Condotel.

\subsection{Research population and sample}

The sample determined as subjects in this study were including infrastructure project stakeholders who had a direct relationship and were able to make a direct impact in the process of implementing an apartment development project, focusing on the main contractor, consultant planners/supervisors, and project owners. The number of samples involved in this study was 55 respondents/construction workers with main contractor 38 respondents, consultant planners 12 respondents and project owner 5 respondents.

\subsection{Research framework}

To achieve the aim of this study, the data needed in this study were primary data and secondary data.

1) Primary Data

Primary data were obtained from respondents/ construction workers by distributing questionnaires and/or conducting interviews directly to respondents, construction workers

2) Secondary Data

Secondary data were obtained from general project data, literature, and media relating to the object under study.

\section{Finding and discussion}

\subsection{Evaluation of measurement model}

Evaluation of the research model was carried out by using the outer model and inner model testing. The outer model that was the initial stage is the evaluation of measurement models that aimed to measure the validity and reliability of the research model to be tested. This test was intended to assess whether the research model was valid and reliable with convergent validity measurement model parameters by looking at loading factor and AVE values. Discriminant validity by looking at the root value of AVE, its correlation with latent variables, and cross-loading values.

Average variance extracted (AVE) Attempts to measure the amount of variance that an LV component captures from its indicators relative to the amount due to measurement error. Proposed threshold value: AVE > 0.5 (Urbach, N. 2010).

Meanwhile, the parameters of the reliability test measurement model were conducted by looking at the results of the Cronbach alpha value and composite reliability $(\mathrm{R})$ as a predictive model parameter. Cronbach alpha value Measures the degree to which the MVs load simultaneously when the LV increases. Alpha values ranges from 0 (completely unreliable) to 1 (perfectly reliable). Proposed threshold value for confirmative (explorative) research: CA $>0.8$ or $0.9(0.7)$. Values must not be lower than 0.6 . Composite reliability (R) Attempts to measure the sum of an LV's factor loadings relative to the sum of the factor loadings plus error variance. Leads to values between 0 (completely unreliable) and 1 (perfectly reliable). Alternative to Cronbach's Alpha, allows indicators to not be equally weighted. Proposed threshold value for confirmative (explorative) research: CA > 0.8 or .09 (0.7). Values must not be lower than 0.6 (Urbach, N. 2010).

\subsection{Convergent validity test}

Convergent validity test was performed to determine the ability of instruments used in this study (Haryono, 2020). A convergent validity test was performed to test whether the variables of a construct are highly correlated. Under the rule of thumb used in this study, the parameter loading measurement value was greater than 0.7 and AVE was greater than 0.5. The test results using SmartPLS generated the loading factor values in the following model path diagram and table.

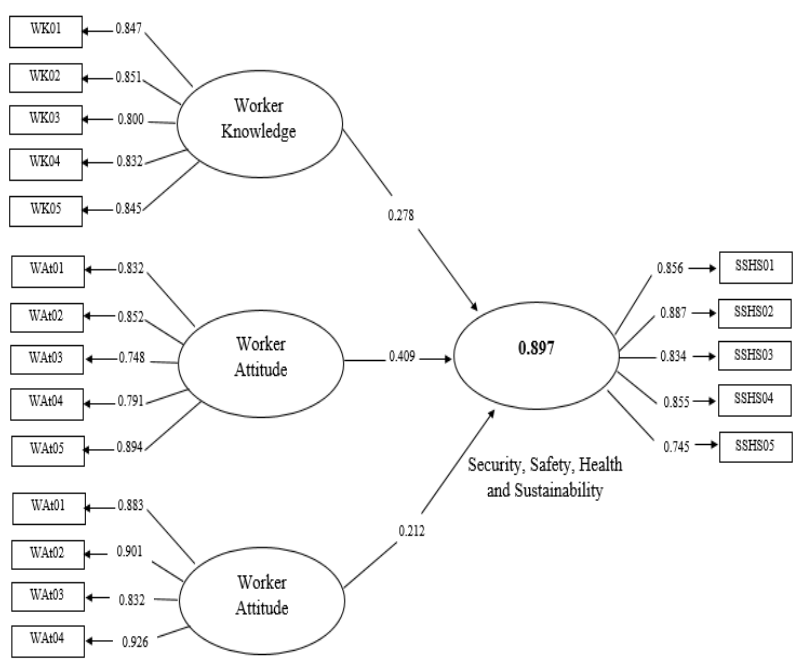

Fig. 1: Path Diagram of Research Models after Calculation.

\begin{tabular}{|c|c|c|c|c|}
\hline & Worker Knowledge & Worker Attitude & Worker Action & Security, Safety, Health and Sustainability \\
\hline WK01 & 0.847 & & & \\
\hline WK02 & 0.851 & & & \\
\hline WK03 & 0.800 & & & \\
\hline
\end{tabular}




\begin{tabular}{|c|c|c|c|c|}
\hline WK04 & 0.832 & & & \\
\hline WK05 & 0.845 & & & \\
\hline WAt01 & & 0.832 & & \\
\hline WAt02 & & 0.852 & & \\
\hline WAt03 & & 0.748 & & \\
\hline WAt04 & & 0.791 & & \\
\hline WAt05 & & 0.894 & & \\
\hline WAc01 & & & 0.883 & \\
\hline WAc02 & & & 0.901 & \\
\hline WAc 03 & & & 0.832 & \\
\hline WAc 04 & & & 0.926 & \\
\hline SSHS01 & & & & 0.856 \\
\hline SSHSO2 & & & & 0.887 \\
\hline SSHS03 & & & & 0.834 \\
\hline SSHS04 & & & & 0.855 \\
\hline SSHS05 & & & & 0.745 \\
\hline
\end{tabular}

Based on the results of outer loading and the values presented in Table 1, it can be concluded that all research indicators got a loading factor value above 0.7 , critical point value of the loading factor value. Thus, it can be interpreted that the research indicators are said to be valid. The next step is to test with the measurement parameters Average Variance Extracted (AVE) > 0.5. The measurement results were presented in Table 2.

Table 2: Average Variance Extracted (AVE)

\begin{tabular}{lll}
\multicolumn{2}{c}{ Table 2: Average Variance Extracted (AVE) } \\
\hline & Average Variance Extracted (AVE) Result & Average Variance Extracted (AVE) Criteria \\
\hline Security, Safety, Health and Sustainability & 0.75 & 0.5 \\
Worker Knowledge & 0.65 & 0.5 \\
Worker Attitude & 0.80 & 0.5 \\
Worker Action & 0.83 & 0.5 \\
\hline
\end{tabular}

Based on measurements by looking at the loading factor value and AVE value, it can be said that all variables and indicators of this study had met the requirements for convergent validity. The values on the measurement of convergent validity are based on the relationship between constructing scores and item scores / component scores. Size higher than 0.7. However, loading values of 0.5 to 0.6 are considered sufficient for initial research development (Ghozali 2006).

Loading Factor Measures how much of the indicators variance is explained by the corresponding LV. Values should be significant at the 0.5 level and higher than 0.7. For exploratory research designs, lower thresholds are acceptable. The significance can be tested using bootstrapping or jackknifing. (Urbach, N. 2010).

\subsection{Reliability test}

A reliability test was done to measure the internal consistency of the measuring instrument. There were two measurement methods, the Cronbach alpha (CA) method and composite reliability (CR) method as a predictive model parameter. To meet the reliability test, the Cronbach alpha (CA) and composite reliability (CR) values have to be $>0.7$.

From the test results listed in Table 3, it can be concluded that the Cronbach alpha value of all variables in this study using the SmartPLS application results was more than 0.7. As for the value of composite reliability in table 4 , all constructs had values above 0.7 . Thus, from the results obtained from the above test, it can be said that all constructs in the model pass the reliability test.

\begin{tabular}{lll} 
Table 3: Cronbach's Alpha & \\
\hline & Cronbach's Alpha Result & Cronbach's Alpha Criteria \\
\hline Security, Safety, Health and Sustainability & 0.90 & 0.7 \\
Worker Knowledge & 0.85 & 0.7 \\
Worker Attitude & 0.93 & 0.7 \\
Worker Action & 0.93 & 0.7 \\
\hline
\end{tabular}

Table 4: Composite Reliability

\begin{tabular}{lll} 
& Table 4: Composite Reliability & Composite Reliability Criteria \\
Security, Safety, Health and Sustainability & Composite Reliability Result & 0.7 \\
Worker Knowledge & 0.93 & 0.7 \\
Worker Attitude & 0.90 & 0.7 \\
Worker Action & 0.95 & 0.7 \\
\hline
\end{tabular}

\subsection{Evaluation of measurement model}

Evaluation of the measurement model discussed the inner model. R-Squares were categorized in 3 categories namely, $0.19<\mathrm{R}-$ Squares $<$ 0.32 as weak category, $0.33<\mathrm{R}$-Squares $<0.67$ as strong category. Table 5 below presents the result of the estimation of R-Squares.

Table 5: R-Squares

\begin{tabular}{ll}
\hline Security, Safety, Health and Sustainability & R Square \\
& 0.897 \\
\hline
\end{tabular}

The table above presents the results of the R-Square value on the Security, Safety, Health, and Sustainability (K4) variables that were 0.897 and included in the strong category. The variable worker knowledge, worker attitude, and worker action gave an effect of $89.7 \%$, while the remaining $10.3 \%$ was influenced by other factors.

\subsection{Calculation of overall model fit}


GoF testing was to measure the activity of the PLS model both at the measurement stage and on the structural model by focusing on the prediction of the overall activities of the model. Furthermore, because the value of R-Squares in this study was 0.897 and the AVE value for $\mathrm{K} 4$ was 0.75 , workers' knowledge is 0.65 , the worker attitude was 0.80 , and worker action was 0.83 . GoF calculations were presented as follows:

Table 6: GoF

\begin{tabular}{lll} 
& \multicolumn{2}{c}{ Table 6: GoF } \\
\hline & GoF Result & GoF Criteria \\
Security, Safety, Health and Sustainability & 0,82 & \\
Worker Knowledge & 0,76 & R-Squares effect Small = 0.2, Medium =0.13, Large = 0.26. \\
Worker Attitude & 0,84 & \\
Worker Action & 0,86 & \\
\hline
\end{tabular}

\subsection{Hypothesis testing}

The next step was to evaluate the t-statistics value for each path to see the significance of constructs. Productiveness can be obtained by bootstrapping to get stability from estimation. Bootstrapping is resampling. PLS uses bootstrapping to determine the t-statistics value to know the level of significance of the t-statistics value. Bootstrapping results can differ each time for it uses the iteration method and each computer has a different iteration. Therefore, bootstrapping > 500 was used to get a stable t-statistic value.

SEM analysis utilized standardized since researchers eager to compare the paths. The recommended t-statistics value should be above 1.96 for the two-tailed hypothesis at alpha 5\%. This study employed the two-tailed hypothesis method. Figure 2 visualized the output of the two-tailed hypothesis measurement model that had been bootstrapping.

The path coefficient results got inner loading values and t-statistics values to assess the significance of the prediction model. The following is the bootstrapping output display. The data presented in the table below used to draw conclusions related to the proposed hypothesis.

Table 7: Path Coefficient Result

\begin{tabular}{lllll}
\hline & Original Sample $(\mathrm{O})$ & Sample Mean $(\mathrm{M})$ & Standard Deviation $(\mathrm{STDEV})$ & T Statistics $(|\mathrm{O} / \mathrm{STDEV}|)$ \\
\hline WK -> K4 & 0.378 & 0.388 & 0.163 & 2.321 \\
WA -> K4 & 0.409 & 0.394 & 0.165 & 2.482 \\
WA -> K4 & 0.212 & 0.218 & 0.101 & 0.021 \\
0.013 & 0.037 \\
\hline
\end{tabular}

The T-statistics column showed that all variables had values above 1.96 . According to the rule of thumb set in this study, it means that all hypotheses are accepted because they had a score above 1.96 .

\begin{tabular}{llll}
\multicolumn{5}{c}{ Table 8: Hypothesis Result } \\
\hline Hypothesis & Variable Relationship & T-statistics & Conclusion \\
\hline H1 & Worker Knowledge $->$ K4 & 2.321 & Hypothesis is accepted \\
H2 & Worker Attitude $->$ K4 & 2.482 & Hypothesis is accepted \\
H3 & Worker Action $->$ K4 & 2.093 & Hypothesis is accepted \\
\hline
\end{tabular}

From the findings presented in table 6, it can be concluded that all hypotheses are accepted.

1) Worker knowledge influences K4. It can be seen from the amount of the T-statistics value of 2.321 (>1.96 for the two-tailed hypothesis).

2) Worker attitude influences K4. It can be seen from the magnitude of T-statistics of 2.482 (>1.96 for the two-tailed hypothesis). Worker actions affect K4, which can be seen from the magnitude of the T-statistics of 2.093 (>1.96 for the two-tailed hypothesis).

\subsection{Expert validation (phase ii questionnaire)}

Then, the second stage questionnaire was conducted on the results of the first stage questionnaire after the statistical analysis was carried out. Three independent variables considered affecting security, safety, health, and sustainability (K4) were passed back to the same expert at the first questionnaire stage. Validation was done by submitting a questionnaire to the experts to find out the opinion of experts whether they agree or not on the results of the three independent variables. Besides that, experts were also asked for their responses and opinions on these factors. Thus, it is expected to be able to provide prevention solutions and to minimize the occurrence of work accidents due to the three variables.

Respondents or construction workers who work in general were always equipped with communication and information related to K4 with each respondent giving varied responses. By looking at the results of the research hypotheses testing, it can be concluded that the workers' knowledge, the worker attitude, and the workers' actions influence K4 since the T-statistics values were above 1.96. The highest path coefficient was the path of worker attitude to K4 with a path coefficient of 0.226 , followed by the worker knowledge of 0.258 , and the worker action of 0.149 .

\subsection{Effect of worker knowledge on security, safety, health and sustainability}

Based on the result of hypothesis testing in the interaction model for all sample data, it can be concluded that in this interaction model, Domination does not give influence upon the increase in Interpersonal Skill of Stakeholders and the Competency having no significant influence upon the Project Success.

The first hypothesis test shows that there was an influence between the factors of knowledge of workers on security, safety, health, and sustainability (K4) with a high level of value. Knowledge of workers also had the second major influence which can be seen from the results of the analysis of the T-statistics value of 2.321 (>1.96 for the two-tailed hypothesis). It can be said that the worker knowledge research variable had a significant influence on K4. It can be concluded that the first hypothesis is said to be accepted.

The results of the above study indicate that the level of knowledge influenced the worker attitude related to K4. The reality of the above findings is in line with the opinions expressed by the third expert on validation who said that the culture of occupational safety and occupational health could be successful if workers aware, understand, and implement the principles of K4. Meanwhile, according to the fourth 
expert, knowledge is highly correlated to the level of worker safety. Moreover, the fifth expert said and needed to always provide comprehensive, specific, and detailed information related to $\mathrm{K} 4$ as well as trying to create work safety at the worksite to increase knowledge for workers

\subsection{Effect of worker attitude on security, safety, health and sustainability}

The second hypothesis test shows that there was an influence between the variables of worker attitude toward security, safety, health, and sustainability (K4). It had a high level of value and the first major influence that can be seen from the results of the analysis of the Tstatistics value of 2.482 ( $>1.96$ for the two-tailed hypothesis). It can be said that the work attitude research variable has a significant influence on K4. It can be concluded that the second research hypothesis is said to be accepted.

The explanation above is in line with the opinion expressed by the third expert who agrees that there was an influence on the habits of workers have a dominant influence on the application of work safety. Moreover, workers who are careless, not vigilant, and do not comply with regulations at work are still exist. Then, there are still many workers who are reluctant to learn about equipment, materials, and so on related to work.

Meanwhile, according to the fourth expert, the attitude of workers also affects the level of safety and security of workers. Moreover, the fifth expert agreed that there is a need to build a conscious and caring attitude towards K4 for all workers through training efforts about the importance of K4.

\subsection{Effect of worker action on security, safety, health and sustainability}

The third hypothesis test shows that there was an influence between the variable of worker action on K4 with a high level of value. It had a large influence that can be seen from the results of the analysis of the T-statistics of 2.093 (>1.96 for the two-tailed hypothesis). It can be said that the variable of worker action had a significant influence on K4. It can be concluded that the third hypothesis is accepted.

The results of the above study indicate that worker attitude related to K4 is influenced by worker actions. The reality of the above findings is in line with the opinion put forward by the third expert who said that the worker attitude related to K4 is influenced by the actions of workers in very influential for there are still many workers who already know the rules but do not implement them. For example, when required to use gloves and protective clothing, the workers do not use it for it is less comfortable for them.

Meanwhile, in the opinion of the fourth expert, the actions of workers both unsafe action and safe actions affect the level of safety. Moreover, the fifth expert stated that the factors that cause work accidents on construction projects are due to lack of quality, skills, and inadequate awareness of workers.

\subsection{Research hypothesis result}

Figure 3 visualizes the final model path diagram after conducting a hypothesis test for variables that affect security, safety, health, and sustainability (K4) in apartment constructions with the following formula:

$\mathrm{Y}=0.258 \mathrm{X} 1+0.266 \mathrm{X} 2+0.149 \mathrm{X} 3+\mathrm{e}$

$\mathrm{Y}=$ Security, Safety, Health, and Sustainability (K4)

$\mathrm{X} 1=$ Worker Knowledge

$\mathrm{X} 2=$ Worker Attitude

$\mathrm{X} 3=$ Worker Actions

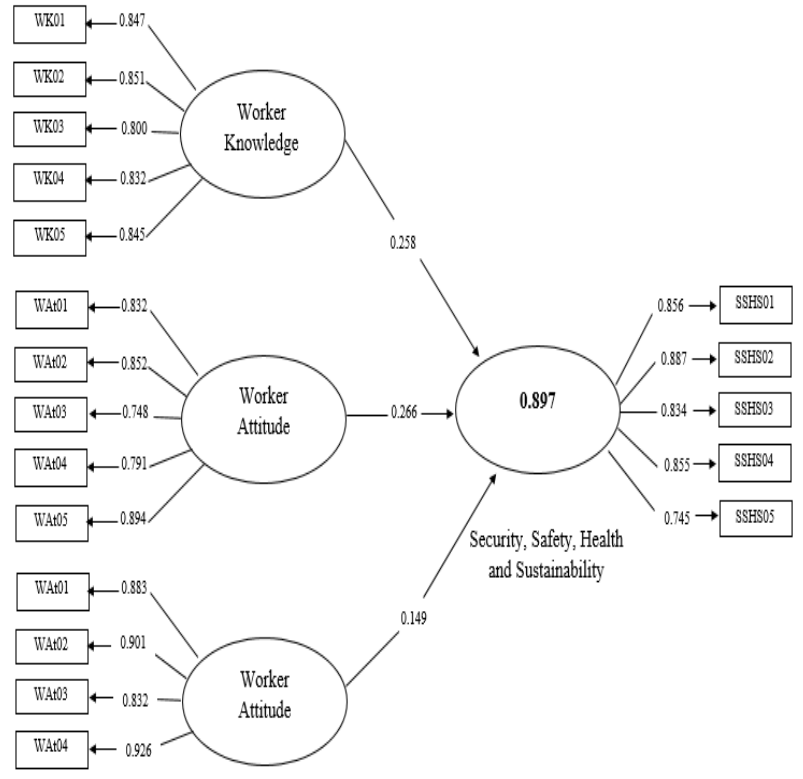

Fig. 2: Final Model Path Diagram.

Table 9: Research Hypothesis Results

\begin{tabular}{lllll}
\hline Hypothesis & Variable Relationship & Path Coef. & Expert Opinion & Conclusion \\
\hline H1 & Worker Knowledge $->\mathrm{K} 4$ & 0.258 & Agree & Hypothesis is accepted \\
H2 & Worker Attittude $>$ K4 & 0.266 & Agree & Hypothesis is accepted \\
H3 & Worker Action $->\mathrm{K} 4$ & 0.149 & Agree & Hypothesis is accepted \\
\hline
\end{tabular}


The results presented in table 7 above can be described as follows:

1) Worker knowledge (X1) influences $\mathrm{K} 4(\mathrm{Y})$ with a path coefficient of 0.258 .

2) Worker attitude (X2) influences $\mathrm{K} 4(\mathrm{Y})$ with a path coefficient of 0.266.

3) Worker actions (X3) affect K4 (Y) with a path coefficient of 0.149.

In this study, it can be concluded that the variable that was very influential on K4 is the worker attitude (X2) with a value of 0.266. Moreover, based on the opinion of the experts, all experts agreed with three variables that affected K4.

\subsection{Conclusion of research hypothesis result}

The analysis results obtained indicate that K4 is highly influenced by the attitude of construction workers. In K4, the government, in particular, the Directorate General of Construction formed the Construction Safety Committee (K2 Committee). The establishment of the K2 Committee aimed to assist the supervision of K3 Construction in Indonesia. The task of the K2 Committee is to monitor projects with a high level of accident risk. Additionally, it also investigates in the event of a construction accident and ensures construction safety, institutional safety, third party safety, and worker safety.

Besides worker attitude, the level of knowledge of workers has an influence on the implementation of K4 for work safety for workers must take precedence. At the level of workers with high knowledge for workers about K4 awareness, it is easier to instill and to achieve the goals of the K4, namely the health and safety targets of work as well as to others, safeguard company assets, protect workers, and ensure continuity of work. The influence of worker attitude towards K4 needs to be given top priority by improving the work ethic of discipline and how to behave in K4. This is not easy to do, but it requires a strong commitment from management and careful safety officers to provide understanding and awareness that complying and implementing K4 that is important for the sake of the workers themselves. The effect of worker actions on K4 indicates that while carrying out their work, the workers must minimize the risk of work accidents by increasing self-awareness of $\mathrm{K} 4$ behavior and always using personal protective equipment that must be used when working.

\section{Conclusion and suggestion}

\subsection{Conclusion}

1) Worker knowledge influences Security, Safety, Health, and Sustainability (K4) with a path coefficient of 0.258 . The level of knowledge of workers has an influence on the implementation of K4, work safety for workers must take precedence. At the level of workers with high knowledge for workers about K4 awareness it is easier to instill and it is easier to achieve the goals of the K4 goal, namely the health and safety targets of work as well as to others, safeguard company assets, protect workers and ensure continuity of work.

2) The worker attitude influences $\mathrm{K} 4$ with a path coefficient of 0.266 . The influence of workers attitudes towards K4 needs to be given top priority, namely to improve the work ethic of discipline and to behave in K4. This is not easy to do, but it requires a strong commitment from management and careful safety officers to provide understanding and awareness that complying and implementing $\mathrm{K} 4$ is very important for the sake of the workers themselves.

3) Worker actions affect $\mathrm{K} 4$ with a path coefficient of 0.149 . The effect of workers' actions on K4 that while carrying out their work the workers must minimize the risk of work accidents such as using personal protective equipment (PPE) while working and selfawareness of Security, Safety, Health, and Sustainability behavior.

\subsection{Suggestion}

1) The importance of the company in establishing a comprehensive $\mathrm{K} 4$ policy as an activity that is inseparable from all activities in the project.

2) In order for workers' knowledge, attitudes and actions to be better, regular and continuous socialization needs to be conducted covering all aspects of $\mathrm{K} 4$ that are tailored to the needs of each worker.

3) For companies, must continue to pay attention and positive response to the safety of workers and improve the ability and skills of workers to help improve understanding of safety aspects among workers.

4) Further research is also expected to be able to add research variables that affect security, safety, health and sustainability (K4) in order to produce a broader picture.

\section{References}

[1] Ghozali, Imam. 2006. Aplikasi Analisis Multivariate Dengan Program SPSS. CetakanKeempat. Semarang: Badan Penerbit Universitas Diponegoro.

[2] Kusmawan, S. d. (2006). Keamanan, Kesehatan dan Keselamatan Kerja. Jakarta: Ghalia Indo.

[3] Neal, A., \& Griffin, M. (2002). Safety Cilmate \& Safety Behaviour. Australian Journal of Management 2002 , volume 27. https://doi.org/10.1177/031289620202701S08.

[4] Notoatmojo, S. (2014). Ilmu Perilaku Kesehatan. Jakarta: Rineka Cipta.

[5] Haryono, S. (2020). Pengaruh Sistem Manajemen K3, Keterikatan Karyawan dan Kepuasan Kerja Terhadap Kinerja Karyawan di PT. anugerah Kridapradana. Thesis. Fakultas Ekonomi dan Bisnis. Universitas Budi Luhur. Jakarta. https://doi.org/10.33603/jibm.v3i1.2080.

[6] Tarwaka, P. M (2017). Keselamatan dan Kesehatan Kerja Manajemen dan Implementasi di Tempat Kerja (Vols. Revisi 1, Cetakan 2). Surakarta: Harapan Press.

[7] Undang-undang No. 2 Tahun 2017 Tentang Jasa Konstruksi.

[8] Urbach, N., \& Ahlemann, F. (2010). Structural Equation Modeling in Information Systems Research Using Partial Least Squares. JITTA: Journal of Information Technology Theory and Application, 11(2), 5.

[9] Wijayanti, N. (2008). Pengaruh Penerapan Safety Management Terhadap Kinerja Produktivitas Tenaga Kerja. Jakarta: Universitas Indonesia 